Article

\title{
Lentinoids A-D, New Natural Products Isolated from Lentinus strigellus
}

\author{
Roger Vásquez ${ }^{1}$, Nivia Rios ${ }^{2}$, Godofredo Solano ${ }^{3}$ and Luis Cubilla-Rios ${ }^{1,4, *}$ \\ 1 Laboratory of Tropical Bioorganic Chemistry, Faculty of Natural, Exact Sciences and Technology, \\ University of Panama, Panama 0824, Panama; royi071123@gmail.com \\ 2 Department of Microbiology, Faculty of Natural, Exact Sciences and Technology, University of Panama, \\ Panama 0824, Panama; toxogondii@gmail.com \\ 3 Centro de Investigaciones en Productos Naturales (CIPRONA), Universidad de Costa Rica, San José 2060, \\ Costa Rica; godofredo.solano@gmail.com \\ 4 Smithsonian Tropical Research Institute, Unit 0948, APO AA 34002-0948, Panama 0843, Panama \\ * Correspondence: luis.cubilla@up.ac.pa; Tel.: +507-6676-5824
}

Received: 26 February 2018; Accepted: 23 March 2018; Published: 28 March 2018

\begin{abstract}
Four novel lentinoids (1-4), along with the known compounds striguellone A (5), isopanepoxydone (6) and panepoxydone (7), were isolated as part of our studies on Lentinus strigellus. The structures of 1-4 have been established by 1D- and 2D-NMR and MS analysis. Compounds (1-3) and (5-7) were tested against Listeria monocytogenes, Enterococcus faecalis, Pseudomonas aeruginosa and Klebsiella pneumoniae. These compounds showed inhibition diameters ranging from 7.5-9.5 mm, however, when the minimum inhibitory concentration (MIC) was determined, only compound 1 showed a significant activity of $200 \mu \mathrm{g} / \mathrm{mL}$. Intermediates for the biosynthesis of the oxygenated cyclohexenyl derivatives isolated from lentinoid fungi (genera Lentinus and Panus) are proposed.
\end{abstract}

Keywords: Lentinus strigellus; lentinoids; antibacterial; panepoxydone; isopanepoxydone

\section{Introduction}

Fungi represent one of the most extensive groups of organisms and it is estimated that there are between 1.5 and 5.1 million species [1]. Their capability to produce secondary metabolites with a wide spectrum of biological activities causes a high level of interest in the scientific community [2]. Some of them are edible and/or have been used in traditional medicine, such as the fungus Lentinus strigellus [3]. In their initial stage of growth, they can sometimes be manipulated to generate new compounds, and they could have interesting properties for biological applications.

The genera Lentinus and Panus have some similarities that have generated controversy in some cases [4]. L. strigellus has also been described as Panus strigellus and Panus rudis var. strigellus [5]. Compounds such as strigellone A (5) [3], isopanepoxydone (6) [6], panepoxydone (7) [6], lentinoid E (8) [7] and other analogues have been reported from L. strigellus [8]. The lentinoids reported here have structural similarities with compounds isolated from species of the genera Panus (rudis and conchatus [6]) and Lentinus (strigosus [9] and connatus [10]). The fundamental structural scaffold of these compounds consists of an isoprenyl residue connected to a polyoxygenated cyclohexenyl unit. Lentinoid E (8) was previously isolated from the dichloromethane fraction obtained from a culture of L. strigellus grown in Sabouraud Dextrose Agar (SDA) adjusted to $\mathrm{pH}=4.6$, and using $\mathrm{CaCl}_{2}$ as elicitor at $26^{\circ} \mathrm{C}$ for 15 days [7].

Continuing our study of L. strigellus, we undertook the analysis of the ethyl acetate fraction of the original extract using flash column chromatography and high performance liquid chromatography (HPLC). Thus, we describe the isolation and structural determination of four new lentinoids (1-4) along with known compounds (5-7) (Figure 1) that showed antibacterial properties. 
<smiles>CC(C)(O)/C=C/C1=C[C@@H](O)[C@@H](O)[C@H](O)C1=O</smiles><smiles>CC(C)=C[C@@H](O)C1=CC(=O)[C@@H](O)[C@H](O)[C@H]1O</smiles><smiles>CC(C)(O)/C=C/C1=C[C@@H](O)[C@@H](O)[C@H](O)[C@H]1O</smiles><smiles>CC(C)(O)/C=C/C1=CC(=O)[C@@H](O)[C@H](O)[C@H]1O</smiles><smiles>C=C(CO)C(=O)OC1CC(=O)C=C(C=CC(C)(C)O)[C@@H]1O</smiles>

O",<smiles>CC(C)(O)/C=C/C1=CC(=O)CC[C@H]1O</smiles><smiles>CC(C)=C[C@@H](O)C1=C[C@@H](O)[C@H]2O[C@H]2C1=O</smiles><smiles>CC(C)=CCC1=CC(=O)[C@H]2[CH][C@H]1[C@H]2O</smiles>

Figure 1. Structures of compounds 1-8.

\section{Results and Discussion}

Compound 1 was obtained as a brown viscous liquid. Its molecular formula, $\mathrm{C}_{11} \mathrm{H}_{16} \mathrm{O}_{5}$, was determined by High-resolution electrospray ionisation time-of-flight mass spectrometry (HR-ESI-TOF-MS) analysis on the basis of its cationized molecular peak [M $+\mathrm{Na}]^{+}$at $m / z 251.0891$. The ion at $m / z 269.0568(100 \%)$ corresponded to $\left[\mathrm{M}+\mathrm{H}_{2} \mathrm{O}+\mathrm{Na}^{+}\right]$and the tandem mass spectrometry $\left(\mathrm{MS}^{2}\right)$ spectrum showed that this ion is derived from the cluster $\left[2 \mathrm{M}+\mathrm{H}_{2} \mathrm{O}+\mathrm{Na}^{+}\right], m / z 497.0824$. The Infrared (IR) spectrum showed bands at 3350 and $1690 \mathrm{~cm}^{-1}$ corresponding to a hydroxyl and carbonyl group, respectively. The nuclear magnetic resonance (NMR) data (Table 1) revealed the existence of an isoprenyl unit: two methyl groups $\left(\delta_{\mathrm{H}} 1.30(\mathrm{~s}) ; \delta_{\mathrm{C}} 29.7\right)$, a quaternary sp ${ }^{3}$ oxycarbon $\left(\delta_{C} 71.4\right)$, and two methines $\operatorname{sp}^{2}\left(\delta_{\mathrm{H}} 6.36,6.44(\mathrm{~d}) ; \delta_{\mathrm{C}} 120.1,143.1\right)$. These signals have been observed in striguellone A (5) [3], a compound previously isolated from a culture of L. strigellus. This was confirmed by the correlation spectroscopy (COSY) experiment.

Table 1. NMR data for compounds 1-2 in MeOH- $d_{4},\left(\mathrm{~J}\right.$ in $\mathrm{Hz} ;{ }^{1} \mathrm{H}-\mathrm{NMR}$ at $400 \mathrm{MHz} ;{ }^{13} \mathrm{C}-\mathrm{NMR}$ at $\left.100 \mathrm{MHz}\right)$.

\begin{tabular}{ccccc}
\hline & \multicolumn{3}{c}{$\mathbf{1}$} & \multicolumn{2}{c}{$\mathbf{2}$} \\
\cline { 2 - 5 } Pos. & $\boldsymbol{\delta}_{\mathbf{C}}$ & $\boldsymbol{\delta}_{\mathbf{H}}$ & $\boldsymbol{\delta}_{\mathbf{C}}$ & $\boldsymbol{\delta}_{\mathbf{H}}$ \\
\hline 1 & $191.8, \mathrm{C}$ & & $136.5, \mathrm{C}$ & \\
2 & $135.2, \mathrm{C}$ & & $125.9, \mathrm{CH}$ & $5.67(\mathrm{br} \mathrm{t} ; 4.0)$ \\
3 & $145.4, \mathrm{CH}$ & $6.89(\mathrm{~d} ; 2.4)$ & $63.9, \mathrm{CH}$ & $4.35(\mathrm{~d} ; 4.4)$ \\
4 & $73.1, \mathrm{CH}$ & $4.41(\mathrm{dd} ; 2.4,8.4)$ & $57.1, \mathrm{CH}$ & $3.37(\mathrm{t} ; 4.0)$ \\
5 & $79.3, \mathrm{CH}$ & $3.63(\mathrm{dd} ; 8.4,11.6)$ & $56.0, \mathrm{CH}$ & $3.49(\mathrm{br} \mathrm{m})$ \\
6 & $68.8, \mathrm{CH}$ & $4.60(\mathrm{~d} ; 11.6)$ & $65.3, \mathrm{CH}$ & $4.59(\mathrm{br} \mathrm{d} ; 4.6)$ \\
$1^{\prime}$ & $120.1, \mathrm{CH}$ & $6.36(\mathrm{~d} ; 16.0)$ & $126.5, \mathrm{CH}$ & $6.15(\mathrm{~d} ; 16.0)$ \\
$2^{\prime}$ & $143.1, \mathrm{CH}$ & $6.44(\mathrm{~d} ; 16.0)$ & $140.9, \mathrm{CH}$ & $6.24(\mathrm{~d} ; 16.0)$ \\
$3^{\prime}$ & $71.4, \mathrm{C}$ & & $71.4, \mathrm{C}$ & \\
$4^{\prime}$ & $29.7, \mathrm{CH} \mathrm{H}_{3}$ & $1.30(\mathrm{~s})$ & $29.9, \mathrm{CH}_{3}$ & $1.30(\mathrm{~s})$ \\
$5^{\prime}$ & $29.7, \mathrm{CH}_{3}$ & $1.30(\mathrm{~s})$ & $29.9, \mathrm{CH}_{3}$ & $1.30(\mathrm{~s})$ \\
\hline
\end{tabular}

In the ${ }^{13} \mathrm{C}$-NMR spectrum, there was a quaternary carbon at $\delta_{C} 191.8$ indicative of an $\alpha, \beta$-unsaturated ketone. The chemical shift for the olefinic proton at C-3 displayed low-field shift at $6.89 \mathrm{ppm}$ and appeared as a doublet, due to the coupling between $\mathrm{H}-3$ and $\mathrm{H}-4$, while in striguellone A, this appears as a singlet at $6.04 \mathrm{ppm}(\mathrm{C}-2)$ due the absence of this coupling. 
The quaternary olefinic carbon $\left(\delta_{C} 135.2\right)$ at the $\alpha$-position of the $\alpha, \beta$-unsaturated ketone displayed a high-field shift in comparison to $C-3\left(\delta_{C} 155.7\right)$ in striguellone $A$; additionally, the methine carbon $\left(\delta_{C} 145.4\right)$ appeared at low-field shift occupying the $\beta$-position. The COSY spectrum revealed correlations between H-3/H-4, H-4/H-5, H-5/H-6 and H-1'/H-2' (Figure 2A). The position of the carbonyl group was confirmed by the heteronuclear multiple-bond correlation (HMBC) experiment (Figure 2A). The nuclear Overhauser-effect spectroscopy (NOESY) experiment showed, clearly, correlation of $\mathrm{H}-1^{\prime} / \mathrm{H}-2^{\prime}$ with $\mathrm{H}-3$ and $\mathrm{H}-4^{\prime} / \mathrm{H}-5^{\prime}$. On the other hand, a correlation between $\mathrm{H}-3$ and $\mathrm{H}-4$ was observed (Figure 2B). No interaction was detected for $\mathrm{H}-4 / \mathrm{H}-5$ and $\mathrm{H}-5 / \mathrm{H}-6$, placing them, in both cases, on opposite sides, which was confirmed by the coupling constants ( 3.6 and $10.8 \mathrm{~Hz}$, respectively). Thereafter, we have assigned the new name lentinoid A to compound 1.

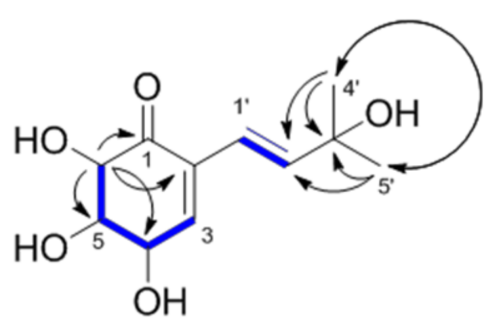

(A)

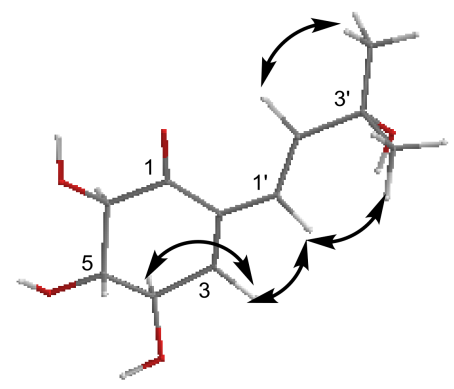

(B)

Figure 2. (A) Correlation spectroscopy (COSY) (in blue boldface), heteronuclear multiple-bond correlation (HMBC) (black arrows) and (B) Overhauser-effect spectroscopy (NOESY) (black arrows) of $\mathbf{1}$.

For compound 2, a brown viscous liquid, the molecular formula $\mathrm{C}_{11} \mathrm{H}_{18} \mathrm{O}_{5}$ was assigned, which has three degrees of unsaturation according to its HR-ESI-TOF-MS data $\left([\mathrm{M}+\mathrm{Na}]^{+}, \mathrm{m} / z\right.$ 253.1034, calcd. 253.1046 for $\left.\mathrm{C}_{11} \mathrm{H}_{18} \mathrm{O}_{5} \mathrm{Na}\right)$. The ion at $\mathrm{m} / \mathrm{z} 235.0940(100 \%)$ in the mass spectrum corresponded to the loss of water $\left[\mathrm{M}+\mathrm{Na}-\mathrm{H}_{2} \mathrm{O}\right]^{+}$, which was confirmed by an $\mathrm{MS}^{2}$ experiment. The IR spectrum showed a band at $3300 \mathrm{~cm}^{-1}$ corresponding to hydroxyl groups, although no signal for a carbonyl group was observed. The COSY and HMBC experiments (Figure 3A) confirmed the presence of an isoprenyl unit as in compound $1\left(\delta_{\mathrm{H}} 1.30(\mathrm{~s}) ; \delta_{\mathrm{C}} 29.9\right)$, a quaternary sp $\mathrm{sp}^{3}$ oxycarbon $\left(\delta_{\mathrm{C}} 71.4\right)$ and two $\mathrm{sp}^{2}$ methines $\left(\delta_{\mathrm{H}} 6.15,6.24(\mathrm{~d}) ; \delta_{\mathrm{C}} 126.5,140.9\right)$. Above, 2 showed a quaternary sp ${ }^{2}$ carbon $\left(\delta_{\mathrm{C}} 136.5\right)$, an sp ${ }^{2}$ methine $\left(\delta_{\mathrm{H}} 5.67(\mathrm{br} \mathrm{t}) ; \delta_{\mathrm{C}} 125.9\right)$ and four sp ${ }^{3}$ oxymethines $\left(\delta_{\mathrm{H}} 3.37(\mathrm{t}), 3.49(\mathrm{br} \mathrm{m}), 4.35(\mathrm{~d}), 4.59\right.$ (br d); $\left.\delta_{C} 57.1,56.0,63.9,65.3\right)$.

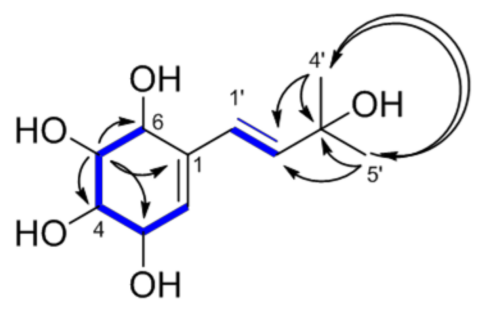

(A)

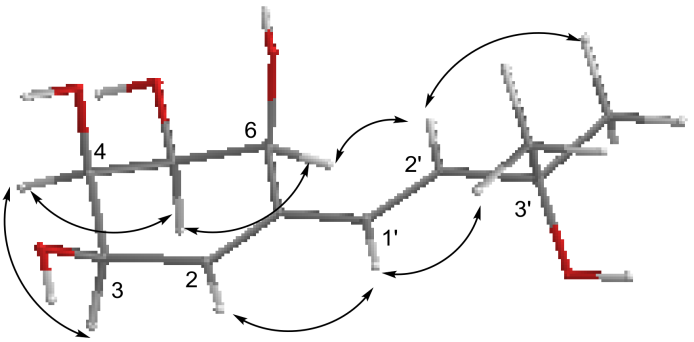

(b)

Figure 3. (A) COSY (in boldface), HMBC (black arrows) and (B) NOESY (black arrows) of 2.

The union of the oxymethines was established based on the COSY experiment (Figure 3A), observing correlations between $\mathrm{H}-2 / \mathrm{H}-3, \mathrm{H}-3 / \mathrm{H}-4, \mathrm{H}-4 / \mathrm{H}-5$ and $\mathrm{H}-5 / \mathrm{H}-6$, and the corresponding coupling constants. The relative stereochemistry was determined taking into account the following 
NOESY correlations: H-3/H-4, H-4/H-5 and H-5/H-6 (Figure 3B and Figure S2.6), as well as the values of the coupling constants (all bellow $4.6 \mathrm{~Hz}$ ) between the hydrogens of the cyclohexyl unit. Therefore, all the hydroxyl groups were determined to be on the same site of the molecule. See ${ }^{1} \mathrm{H}-$ and ${ }^{13} \mathrm{C}$-NMR data in Table 1 . We have assigned the new name lentinoid $\mathrm{B}$ to compound 2.

For lentinoid $\mathrm{C}(3)$, the molecular formula $\mathrm{C}_{15} \mathrm{H}_{20} \mathrm{O}_{7}$ was assigned with six degrees of unsaturation according to its HR-ESI-TOF-MS data, $[\mathrm{M}+\mathrm{Na}]^{+}, \mathrm{m} / z 335.1109$ (calcd. 335.1101 for $\mathrm{C}_{15} \mathrm{H}_{20} \mathrm{O}_{7} \mathrm{Na}$ ), with the bimolecular ion presented at $m / z$ 647.2311. The IR spectrum showed a band at $3400 \mathrm{~cm}^{-1}$ corresponding to an $\mathrm{OH}$ group, and two bands for carbonyl groups: $1632 \mathrm{~cm}^{-1}$ for an $\alpha, \beta$-unsaturated ketone and $1649 \mathrm{~cm}^{-1}$ for an $\alpha, \beta$-unsaturated ester. Compound 3 showed similar NMR data (Table 2) to striguellone $A$, including the prenyl unit (two methyls $\left(\delta_{C} 29.6\right.$ and 29.7), an oxygenated quaternary carbon $\left(\delta_{C} 71.6\right)$, two sp ${ }^{2}$ carbons $\left(\delta_{C} 126.6\right.$ and 149.5)) and the $\alpha, \beta$-unsaturated ketone (carbonyl group $\left(\delta_{C} 194.9\right)$, an $\mathrm{sp}^{2}$ quaternary carbon $\left(\delta_{C} 156.9\right)$ and $\mathrm{sp}^{2}$ methyne $\left.\left(\delta_{C} 125.9\right)\right)$. Moreover, three oxygenated $\mathrm{sp}^{3}$ carbons were present $\left(\delta_{C} 76.6,71.8\right.$ and 67.9$)$. Altogether, the signals resemble the prenyl group and the cyclohexenyl ketone characteristic of lentinoids.

Table 2. NMR data for compound 3 in MeOH- $d_{4},\left(J\right.$ in $\mathrm{Hz} ;{ }^{1} \mathrm{H}-\mathrm{NMR}$ at $600 \mathrm{MHz} ;{ }^{13} \mathrm{C}-\mathrm{NMR}$ at $\left.150 \mathrm{MHz}\right)$.

\begin{tabular}{cccccc}
\hline Pos. & $\delta_{\mathbf{C}}$ & $\delta_{\mathbf{H}}$ & Pos. & $\delta_{\mathbf{C}}$ & $\delta_{\mathbf{H}}$ \\
\hline 1 & 194.9 & & $3^{\prime}$ & 71.6 & \\
2 & 125.9 & $6.02(1 \mathrm{H}, \mathrm{s})$ & $4^{\prime}$ & 29.7 & $1.37(3 \mathrm{H}, \mathrm{s})$ \\
3 & 156.9 & & $5^{\prime}$ & 29.6 & $1.36(3 \mathrm{H}, \mathrm{s})$ \\
4 & 67.9 & $4.72(1 \mathrm{H}, \mathrm{d} ; 3.6)$ & $1^{\prime \prime}$ & 167.0 & \\
5 & 71.8 & $4.05(1 \mathrm{H}, \mathrm{dd} ; 3.6,10.8)$ & $2^{\prime \prime}$ & 141.6 & \\
6 & 76.6 & $5.72(1 \mathrm{H}, \mathrm{d} ; 10.8)$ & $3^{\prime \prime}$ & 125.5 & $5.96(1 \mathrm{H}, \mathrm{m}) 6.35(1 \mathrm{H}, \mathrm{m})$ \\
$1^{\prime}$ & 126.6 & $6.46(1 \mathrm{H}, \mathrm{d} ; 16,0)$ & $4^{\prime \prime}$ & 61.6 & $4.34(2 \mathrm{H}, \mathrm{m})$ \\
$2^{\prime}$ & 149.5 & $6.64(1 \mathrm{H}, \mathrm{d} ; 16,0)$ & & & \\
\hline
\end{tabular}

Additionally, the NMR data revealed the existence of a terminal methylene $\left(\delta_{\mathrm{C}} 125.5, \delta_{\mathrm{H}} 5.96\right.$ and 6.35), a hydroxymethylene $\left(\delta_{C} 61.6, \delta_{\mathrm{H}} 4.34\right)$ and two quaternary carbons $\left(\delta_{C} 141.6\right.$ and $\left.\delta_{C} 167.0\right)$, with the last one characteristic of a carboxyester group. The 2D NMR data (Figure 4A) showed the correlations between all protons and carbons for this fragment of compound 3 . Moreover, the connection of the carboxy group and the cyclohexenyl ring was established through the correlation of $\mathrm{H}-6\left(\delta_{\mathrm{H}} 5.72, \delta_{\mathrm{C}} 76.6\right)$ to both carbonyl groups $\left(\delta_{\mathrm{C}} 167.0\right.$ and 194.9$)$ in equal intensity.

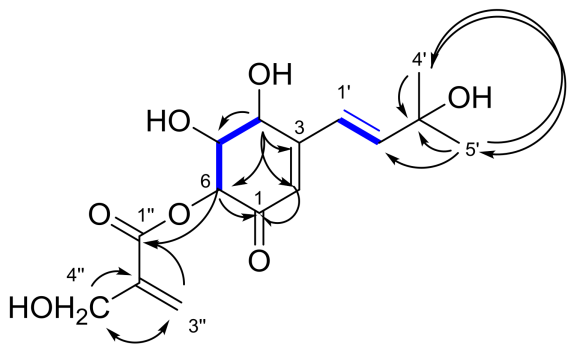

(A)

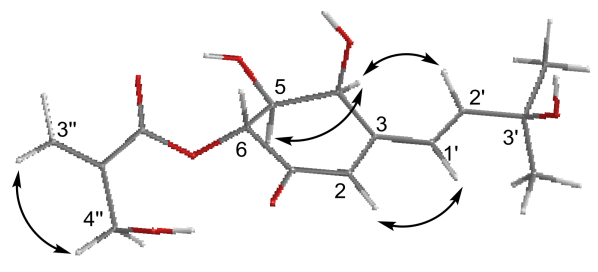

(B)

Figure 4. (A) COSY (in blue boldface), HMBC (black arrows) and (B) ROESY (black arrows) of 3.

The rotating frame overhauser effect spectroscopy (ROESY) experiment (Figure 4B) showed correlation between $\mathrm{H}-4$ and $\mathrm{H}-5$, indicating that they are on the same site of the molecule, and this was confirmed by the coupling constant of $3.6 \mathrm{~Hz}$. No correlation between H-5 and H- 6 was observed, indicating that they are in axial positions with a coupling constant of $10.8 \mathrm{~Hz}$. Thus, the relative stereochemistry of compound 3 was established.

Due to possible instability and the small amount of compound 4 obtained, the structure was characterized by its ${ }^{1} \mathrm{H}-\mathrm{NMR}$ spectrum. Compound 4 showed signals for the isoprenyl group as 
in panepoxydone (7) characterized by two methyl groups attached to an $\mathrm{sp}^{2}$ carbon $\left(\delta_{\mathrm{H}} 1.69\right.$ and $1.70)$, a methyne $\left(\delta_{\mathrm{H}} 5.29, \mathrm{~d}, J=8.8 \mathrm{~Hz}\right)$ and a hydroxymethyne $\left(\delta_{\mathrm{H}} 5.00, \mathrm{~d}, J=8.8 \mathrm{~Hz}\right)$. Based on the chemical shift for the other three hydroxymethynes, the coupling constants $\left(\mathrm{H}-6: \delta_{\mathrm{H}} 3.96, \mathrm{~d}, 12.0 ; \mathrm{H}-5\right.$ : $\delta_{\mathrm{H}}$ 3.63, dd, 8.4 and 12.0; H-4: $\left.\delta_{\mathrm{H}} 4.36, \mathrm{~d}, 8.4\right)$, and the olefin proton $\left(\delta_{\mathrm{H}} 6.89\right)$ with a chemical shift characteristic of an $\alpha$-proton in an $\alpha, \beta$-unsaturated ketone, we proposed a structure for the newly discovered lentinoid D (4).

This group of compounds, isolated from lentinoid species (Lentinus and Panus), is characterized by an isoprenyl residue and an oxygenated cyclohexenyl ring, and could have similar biogenetic precursors. In Scheme 1, we proposed a not-yet-isolated precursor (I), and the structure of three possible intermediates (II-IV, in red) for the generation of this series of molecules. The biosynthesis may include two subsequent oxidation reactions of the not-yet-isolated compounds I, IIIa, IIIb and the newly reported lentinoid B (2). Compounds I, IIIa and IIIb (in blue) could be produced by some species of the genus Lentinus under different culture conditions.<smiles>CC(C)=CC=C1C(O)C(O)C(O)C(O)C1O</smiles>

Oi."<smiles>CC(C)=CC=C1C(=O)CCC(O)C1O</smiles>

Oi:.<smiles>CC(C)=CC=C1C(O)CCC(O)C1O</smiles>

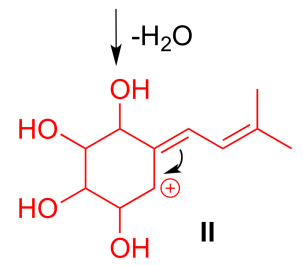<smiles>[3H][V]</smiles><smiles>C=C([C+]1C=C(C)CC1C)C(O)C(C)O</smiles><smiles>CC(C)=CC(O)C1=CC(O)C(O)C(O)C1O</smiles>

Oi:

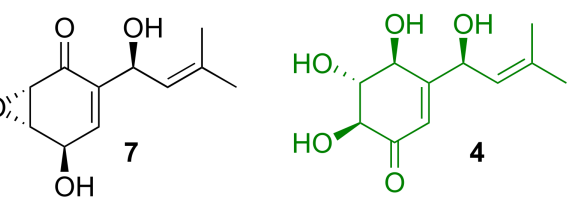

O),<smiles>CC(C)=CC(O)C1=CC(=O)CCC1=O</smiles><smiles>[C-]1C=C1</smiles><smiles>CC(C)=CCC1=CC(=O)CCC1O</smiles>

Oi."<smiles>CC(C)=CCC1=CC(O)CCC1O</smiles>

IV<smiles>CCO[C@H]1C(/C=C/C(C)(C)O)=C[C@@H](O)[C@H](O)[C@H]1O</smiles><smiles>CC(C)(O)/C=C/C1=C[C@H](O)[C@@H](O)C(O)C1=O</smiles><smiles>CC(C)(O)/C=C/C1=CC(=O)[C@H](O)[C@H](O)[C@H]1O</smiles><smiles>CC(C)(O)/C=C/C1=CC(=O)C[C-]C1O</smiles>

Scheme 1. Proposed intermediates for the biosynthesis of the lentinoids, oxygenated cyclohexenyl derivatives, isolated from species of the genera Lentinus and Panus. Intermediates are in red. Compounds 1-2 and 4 are in green, the structure of not-yet-isolated compounds are in blue, and previously isolated compounds are in black: striguellone A (5), isopanepoxydone (6), panepoxydone (7), lentinoid E (8), 7-desoxypanepoxydol (9), panepoxydione (10), neopanepoxydone (11), and neopanepoxydol (12). 


\section{Antibacterial Activity}

The bacterial growth inhibition was evaluated in vitro by the disc diffusion method [11]. Compounds 1-3 and 5-7 were tested at a concentration of $6.25 \mu \mathrm{g} / \mu \mathrm{L}$ against Listeria monocytogenes, Enterococcus feacalis, Pseudomonas aeruginosa and Klebsiella pneumoniae. The first three bacteria were inhibited by at least one of the compounds with an inhibition diameter (ID) ranging from 7.5-9.5 mm. No antibacterial activity was detected against K. pneumoniae. The positive control used was gentamycin sulfate (ID, 15-25 mm) at a concentration of $1.25 \mu \mathrm{g} / \mu \mathrm{L}$ (Table 3).

Table 3. Antibacterial activity of compounds 1-3 and 5-7, inhibition diameter (mm).

\begin{tabular}{lccccccc}
\hline \multirow{2}{*}{ Bacteria Species } & \multicolumn{9}{c}{ Compounds } & \multicolumn{2}{c}{ Positive Control } \\
\cline { 2 - 8 } & $\mathbf{1}$ & $\mathbf{2}$ & $\mathbf{3}$ & $\mathbf{5}$ & $\mathbf{6}$ & $\mathbf{7}$ & Gentamycin Sulfate \\
\hline Listeria monocytogenes & $\mathrm{I}$ & $\mathrm{I}$ & $\mathrm{I}$ & $\mathrm{I}$ & 7.5 & $\mathrm{I}$ & 25 \\
Enterococcus faecalis & 9 & 9 & 8 & 8 & 9.5 & $\mathrm{I}$ & 15 \\
Pseudomonas aeruginosa & $\mathrm{I}$ & 9.5 & $\mathrm{I}$ & 7.5 & 8.5 & $\mathrm{I}$ & 20 \\
\hline
\end{tabular}

The minimum inhibitory concentration (MIC) was determined for compounds 1, 2 and 3 using E. faecalis and P. aeruginosa (Table 4); nevertheless, only compound 1 resulted in a significant MIC; to inhibit E. faecalis, twice the amount of lentinoid A will be required. This could indicate that the presence of the carbonyl group is necessary for the antibacterial activity of lentinoid A compared to lentinoid B.

Table 4. Antibacterial activities of compounds 1-3, MIC ( $\mu \mathrm{g} / \mathrm{mL})$.

\begin{tabular}{ccccc}
\hline \multirow{2}{*}{ Bacteria Species } & \multicolumn{3}{c}{ Compounds } & Positive Control \\
\cline { 2 - 5 } & $\mathbf{1}$ & $\mathbf{2}$ & $\mathbf{3}$ & Gentamycin Sulfate \\
\hline E. faecalis & 200 & - & - & 100 \\
P. aeruginosa & - & 160 & - & 33 \\
\hline
\end{tabular}

\section{Materials and Methods}

\subsection{General}

General experimental procedures. Optical rotations were measured in methanol on an Autopol V Plus Automatic Polarimeter (Whashington, NJ, USA) using a $10 \mathrm{~cm}$ cell. Ultra violet spectra were determined on a Waters 2996 PDA detector (Waters, Milford, MA, USA). IR spectra were determined using an Agilent Cary 630 FTIR spectrophotometer (film) (Agilent, Santa Clara, CA, USA). NMR spectra including 1D and 2D experiments were recorded at $400 \mathrm{MHz}$ (JEOL, Ltd. Tokyo, Japan) and $600 \mathrm{MHz}$ (Bruker, Billerica, MA, USA) using $\mathrm{CD}_{3} \mathrm{OD}$ and $\mathrm{CDCl}_{3}$ as solvents with tetramethylsilane (TMS) as internal standard. HRMS spectra were acquired on a Bruker micrOTOF-QIII (ESI-TOF), direct injection (Bruker, Billerica, MA, USA). The flash columns were made using silica gel 100 (70-230 mesh ASTM, Merck, Darmstadt, Germany) and silica gel (200-400 mesh, $60 \AA$, Sigma-Aldrich, St. Louis, MO, USA), the fractions collected were monitored by Sigma-Aldrich TLC plates 3110 (Sigma-Aldrich, St. Louis, MO, USA) and spots were detected using $p$-anisaldehyde spray reagent after heating. HPLC separations (Waters Delta 600) were carried out using a normal-phase semi-preparative column (YMC-Pack Sil, S-5 m, 12 nm, $150 \times 10$ mm ID), a chiral column (QuiralPack IA, $5 \mu \mathrm{m} 150 \times 4.6 \mathrm{~mm}$ ID, Daicel Corporation, Tokyo, Japan) and a photodiode array detector Waters 2996. The injector was equipped with a $200 \mu \mathrm{L}$ loop. Chemical structures (1D and 3D (force field MM2)) were drawn using Chemdraw (Perkin Elmer, Waltham, USA), version: 16.0.1.4. 


\subsection{Fungal Material}

Fruiting bodies of Lentinus strigellus (collection number LC46) [7] were collected on burned wood near La Nevera highway in the Boquete, a region of Chiriquí Province in Panamá. The specimen was identified as Lentinus strigellus using molecular phylogenetic analyses. The air-dried specimens were deposited at the National Herbarium of the University of Panamá (PMA115711) and in the Herbarium of the Autonomous University of Chiriquí (UCH7481), Panamá.

\subsection{Cultivation and Crude Extract}

Initially, L. strigellus was cultivated in potato dextrose agar (PDA), malt extract agar (MEA) and Sabouraud Dextrose Agar (SDA) using six petri dishes each for 15 days. The chemical compositions of these three extracts were analyzed by thin-layer chromatography and NMR spectroscopy. A greater chemical diversity in the SDA extract using this analysis was detected. Hence, SDA cultivation was evaluated further, including the addition of the elicitors: arginine, glutamic acid, $\mathrm{CaCl}_{2}, \mathrm{CuSO}_{4}$ and $\mathrm{FeSO}_{4}$, and at three different $\mathrm{pH}$ values: 4.6, 5.6 and 6.6. The period of 15 days and temperature at $26^{\circ} \mathrm{C}$ were the same for all experiments. The biomass yield $(221 \mathrm{mg})$ was the highest for SDA with $\mathrm{CaCl}_{2}$ and a pH of 4.6 (calcium in low concentration tends to increase the yield of biomass produced [11]; in some cases this could bind proteins causing conformational changes and activating or inactivating mechanisms of catalysis [12]).

Culturing involving 67 petri dishes and the optimal conditions resulted in $3.10 \mathrm{~g}$ of crude ethyl acetate extract. To prepare the extract, the content of 15 petri dishes was transferred into one $1 \mathrm{~L}$ glass flask, with $400 \mathrm{~mL}$ of ethyl acetate, and extracted by sonicating for $20 \mathrm{~min}$. This was repeated four times. The extract was recovered by drying under reduced pressure at $30{ }^{\circ} \mathrm{C}$ [7].

\subsection{Compound Isolation}

$3.0 \mathrm{~g}$ of crude extract was fractionated by flash chromatography $(4 \mathrm{~cm}$ ID) using silica gel (200-400 mesh, $10 \mathrm{~g}$ ) and $1 \mathrm{~L}$ each of the following solvents: $n$-hexane, $\mathrm{CH}_{2} \mathrm{Cl}_{2}$, EtOAc, acetonitrile and water. All fractions (A-E) were analyzed by TLC. Fraction C (EtOAc), having a mass of $1561.4 \mathrm{mg}$ (50.4\%), was subjected to flash chromatography ( $2.5 \mathrm{~cm}$ ID) using silica gel (200-400 mesh, $70 \mathrm{~g}$ ), and eluted with a gradient system from $100 \% \mathrm{CH}_{2} \mathrm{Cl}_{2}$ to $100 \%$ EtOAc followed by a gradient from $100 \%$ EtOAc to $100 \% \mathrm{MeOH}$ to afford 8 fractions ( $\mathrm{C} 1$ to $\mathrm{C} 8$ ).

Fraction C6 (74.1 mg, 4.7\%) was purified by normal-phase HPLC using a linear gradient (from 75:25 $n$-hexane-isopropanol to $40: 60 \mathrm{n}$-hexane-isopropanol at $1.00 \mathrm{~mL} / \mathrm{min}$ ) in $55 \mathrm{~min}$, to give 4 fractions, where the peak at $t_{\mathrm{R}} 17 \mathrm{~min}$ corresponded to panepoxydone (7) $(8.1 \mathrm{mg}, 10.9 \%)$ and the peak at $t_{\mathrm{R}} 21.5 \mathrm{~min}$ corresponded to isopanepoxydone (6) (12.3 mg, 16.6\%).

Fraction C7 (235.0 mg, 15.1\%) was flash chromatographed (2 cm ID) with silica gel (200-400 mesh, $22 \mathrm{~g})$, and $n$-hexane/EtOAc $(v / v=100: 0-0: 100)$ and EtOAc/MeOH $(v / v=100: 0-0: 100)$ as eluents, to give 14 fractions (C7.1 to C7.14). C7.9 (76.2 mg, 32.4\%) was subjected to normal-phase HPLC using a linear gradient (from 75:25 n-hexane-isopropanol to 40:60 $n$-hexane-isopropanol at $1.00 \mathrm{~mL} / \mathrm{min}$ ) in $55 \mathrm{~min}$, to give 3 fractions, where the peak at $t_{\mathrm{R}} 18 \mathrm{~min}$ corresponds to striguellone $\mathrm{A}(5)$ and the peak at $t_{\mathrm{R}} 23$ min corresponds to lentinoid A (1).

Fraction C7.10 (55.0 mg, 23.4\%) was purified by normal-phase HPLC using a linear gradient (of 75:25 $n$-hexane-isopropanol to 40:60 $n$-hexane-isopropanol at $1.00 \mathrm{~mL} / \mathrm{min}$ ) in $55 \mathrm{~min}$, to give 6 fractions (I-VI), where the peak at $t_{\mathrm{R}} 33 \mathrm{~min}$ (fraction VI) corresponds to lentinoid B (2) $7.4 \mathrm{mg}$ (13.5\%). Fraction V (26.0 mg, 47.3\%) was purified by normal-phase HPLC using a linear gradient (85:15 to $30: 70 \mathrm{n}$-hexane-isopropanol at $1.00 \mathrm{~mL} / \mathrm{min}$ ) in $55 \mathrm{~min}$, to give 3 fractions (V.1 to V.3). V.1 (7.3 mg, 28.1\%) was purified by HPLC (Chiral Pack IA, $5 \mu \mathrm{m}, 150 \times 4.6 \mathrm{~mm}$ ID) using the isocratic $85: 15 n$-hexane-isopropanol at $0.50 \mathrm{~mL} / \mathrm{min}$ to give lentinoid $\mathrm{C} \mathrm{(3)}\left(t_{\mathrm{R}} 17 \mathrm{~min} ; 2.6 \mathrm{mg}\right.$, $35.6 \%)$. V.2 (5.4 mg, 20.8\%) was purified by HPLC (Chiral Pack IA, $5 \mu \mathrm{m}, 150 \times 4.6 \mathrm{~mm}$ ID) using the isocratic 85:15 n-hexane-isopropanol at $0.50 \mathrm{~mL} / \mathrm{min}$ to give lentinoid $\mathrm{D}(4)\left(t_{\mathrm{R}} 12 \mathrm{~min} ; 1 \mathrm{mg}, 13.7 \%\right)$. 


\subsection{Lentinoid A (1)}

Brown viscous liquid; $[\alpha]_{\mathrm{D}}^{25}-64.5$ (c $\left.0.0029, \mathrm{MeOH}\right) ; \mathrm{UV}(\mathrm{MeOH}) \lambda_{\max } 273$ and $212 \mathrm{~nm}$; IR mmax: 3350, 2948, 2876, 1690, 1390 and $1040 \mathrm{~cm}^{-1} ;{ }^{1} \mathrm{H}$ - and ${ }^{13} \mathrm{C}-\mathrm{NMR}$ data, see Table $1 ;$ (+)-HR-ESI-TOF-MS $m / z 251.0891$ (calcd. 251.0890 for $\mathrm{C}_{11} \mathrm{H}_{16} \mathrm{O}_{5} \mathrm{Na}$ ).

\subsection{Lentinoid B (2)}

Brown viscous liquid; $[\alpha]_{\mathrm{D}}^{25}+3.3$ (c $\left.0.0024, \mathrm{MeOH}\right)$; UV (Hx/IP) $\lambda_{\max } 233 \mathrm{~nm}$; IR mmax: 3300, 2942, 2831 and $1021 \mathrm{~cm}^{-1} ;{ }^{1} \mathrm{H}$ - and ${ }^{13} \mathrm{C}-\mathrm{NMR}$ data, see Table $1 ;(+)$-HR-ESI-TOF-MS $\mathrm{m} / z 253.1034$ [M + $\mathrm{Na}]^{+}$(calcd. 253.1046 for $\mathrm{C}_{11} \mathrm{H}_{18} \mathrm{O}_{5} \mathrm{Na}$ ).

\subsection{Lentinoid C (3)}

Brown viscous liquid; $[\alpha]_{\mathrm{D}}^{25}-75.0$ (c 0.0005, MeOH); UV (MeOH) $\lambda_{\max } 278$ and $208 \mathrm{~nm}$; IR mmax: 3280, 2951, 2840, 1649, 1632 and $1013 \mathrm{~cm}^{-1} ;{ }^{1} \mathrm{H}$ - and ${ }^{13} \mathrm{C}-\mathrm{NMR}$ data, see Table 2; (+)-HR-ESI-TOF-MS $m / z 335.1109$ (calcd. 335.1101 for $\mathrm{C}_{15} \mathrm{H}_{20} \mathrm{O}_{7} \mathrm{Na}$ ).

\subsection{Antibacterial Activities [13,14]}

The antibacterial activity was determined through the susceptibility test of the British Society for Antimicrobial Chemotherapy (BSAC).

\subsubsection{Preparation of 0.5 McFarland Turbidity Standard}

The turbidity standard was prepared using $0.5 \mathrm{~mL}$ of solution of $\mathrm{BaCl}_{2}\left(\mathrm{BaCl}_{2} .2 \mathrm{H}_{2} \mathrm{O} ; 0.048 \mathrm{M}\right)$ in a tube containing $99.5 \mathrm{~mL}$ of $\mathrm{H}_{2} \mathrm{SO}_{4}(0.18 \mathrm{M})$. The absorbance of the McFarland standard (between 0.08 and 0.10 at $625 \mathrm{~nm}$ ) was verified using a spectrophotometer. The solution was stored in the dark at $24 \pm 2{ }^{\circ} \mathrm{C}$.

\subsubsection{Preparation of Bacterial Inoculum}

Each bacterium was cultivated in Tripticase Soy Agar (TSA) for 24 h; thereafter, five colonies were chosen and transferred into a tube containing saline and isotonic solution and then visually compared with the $0.5 \mathrm{McF}$ arland standard.

\subsubsection{Bacterial Growth Inhibition in Vitro}

The bacterial growth inhibition was evaluated in vitro by the disc diffusion method using Trypticase Soy Agar (TSA) in Petri dishes $(145 \mathrm{~mm})$ and placing a disc (6 mm diameter) with $50 \mu \mathrm{g}$ of each tested compound dissolved in DMSO. The plate was then incubated for $18 \mathrm{~h}$ at $37^{\circ} \mathrm{C}$, and the inhibition area were measured. For the positive control, gentamycin sulfate $(10 \mu \mathrm{g} / \mathrm{mL})$ was used and the negative control was DMSO. The diameter of the inhibition around each disk was measured, providing a measure of zone-of-inhibition (ZOI) in mm (including the diameter of the disc).

\subsubsection{Minimum Inhibitory Concentration (MIC)}

The minimum inhibitory concentration (MIC) was determined using a stock solution prepared by adding $300 \mu \mathrm{g}$ of each compound in $3 \mathrm{~mL}$ of Trypticase Soy Broth (TSB). Serial dilutions of the evaluated compounds and control were performed to determine the MIC. The evaluated concentrations of each compound were 100.0, 40.0, 33.3, 11.1 and $5.6 \mu \mathrm{g} / \mathrm{mL}$. Each solution was thereafter inoculated with $50 \mu \mathrm{L}$ (0.5 McFarland) of a culture of E. faecalis and P. aeruginosa, and incubated at $37^{\circ} \mathrm{C}$ for $18 \mathrm{~h}$. The positive control (gentamycin sulfate $10 \mathrm{mg} / \mathrm{mL}$ ) concentrations were similar to those of the compounds. Additionally, two blanks were used, one with culture medium alone and one with DMSO. Each assay was performed in duplicate. 


\section{Conclusions}

In summary, we have characterized four new lentinoids produced by L. strigellus as a response to changes in culture conditions. They represent new additions to the chemical diversity produced by this fungus. The compounds represented in Scheme 1, isolated from the genera Lentinus and Panus, could have similar precursors. Additional improvements to the experimental culture conditions and the use of additional analytical tools could lead to the isolation of new compounds of this class and therefore new active molecules. Moreover, three of these compounds showed antibacterial activity in a bacterial growth inhibition assay (inhibition zone in $\mathrm{mm}$ ). However, when the minimum inhibitory concentration (MIC) was determined, only compound 1 showed a significant activity of $200 \mu \mathrm{g} / \mathrm{mL}$.

Supplementary Materials: The following are available online, ${ }^{1} \mathrm{H}$ - and ${ }^{13} \mathrm{C}-\mathrm{NMR}, 2 \mathrm{D}$ NMR and MS data for compounds 1-3 and ${ }^{1} \mathrm{H}-\mathrm{NMR}$ for compound 4. The isolations chromatograms for each novel compound are present.

Acknowledgments: This work was supported by grants from SENACYT-Panama (COL10-060 and FID11-051), the Project of Nagoya Protocols' Application in Panamá and the National Research System (SNI). We also give our thanks to the personnel of Panamá's Ministry of Environment for their assistance in obtaining the collect permit.

Author Contributions: Roger Vásquez carried out the experimental work (isolation and structural elucidation of compounds) and drafted the manuscript. Nivia Rios culture of fungi and development of the antibacterial assays. Godofredo Solano assisted in the acquisition of some NMR data and its interpretation. Luis Cubilla-Rios design the project, contributed in the structural characterization and wrote the manuscript.

Conflicts of Interest: The authors declare no conflict of interest.

\section{References}

1. Raja, H.A.; Miller, A.N.; Pearce, C.J.; Oberlies, N.H. Fungal Identification Using Molecular Tools: A Primer for the Natural Products Research Community. J. Nat. Prod. 2017, 80, 756-770. [CrossRef] [PubMed]

2. Hoffmeister, D.; Keller, N.P. Natural products of filamentous fungi: Enzymes, genes, and their regulation. Nat. Prod. Rep. 2007, 24, 393-416. [CrossRef] [PubMed]

3. Zheng, Y.; Zhao, B.; Lu, C.; Lin, X.; Zheng, Z.; Su, W. Isolation, structure elucidation and apoptosis-inducing activity of new compounds from the edible fungus Lentinus striguellus. Nat. Prod. Commun. 2009, 4, 501-506. [PubMed]

4. Senthilarasu, S. The lentinoid fungi (Lentinus and panaus) from Western Ghats, India. IMA Fungus 2015, 6, 119-128. [CrossRef] [PubMed]

5. Guzmán, G.; Piepenbring, M. Los hongos de Panamá-Introducción a la Identificación de los Macroscópicos, 1st ed.; Instituto de Ecología, A.C.: Xalapa, Veracruz, México, 2011; p. 150.

6. Kis, Z.; Closse, A.; Sigg, H.P.; Hruban, L.; Snatzke, G. Die Structure von Panepoxydon und verwandten Pilzmetaboliten. Helv. Chim. Acta 1970, 53, 1577-1597. [CrossRef]

7. Julca-Canto, M.; Aguilar-Pérez, M.M.; Rios, N.; Sousa, J.P.B.; Cubilla-Rios, L. Additional new natural products produced by Lentinus strigellus: A biotechnological approach. Tetrahedron Lett. 2016, 57, 650-653. [CrossRef]

8. Barros-Filho, B.A.; de Oliveira, M.C.; Mafezoli, J.; Barbosa, F.G.; Rodrigues-Filho, E. Secundary metabolite production by the basidiomycete, Lentinus strigellus, under different culture conditions. Nat. Prod. Commun. 2012, 7, 771-773. [PubMed]

9. Souza-Fagundes, E.M.; Cota, B.B.; Rosa, L.H.; Romanha, A.J.; Correa-Oliveira, R.; Rosa, C.A.; Zani, C.L.; Teixeira-Carvalho, A.; Martins-Filho, O.A. In vitro activity of hypnophilin from Lentinus strigosus: A potential prototype for Chagas disease and leishmaniasis chemotherapy. Braz. J. Med. Biol. Res. 2010, 43, 1054-1061. [CrossRef] [PubMed]

10. Rukachaisirikul, V.; Tansakul, C.; Saithong, S.; Pakawatchai, C.; Isaka, M.; Suvannakad, R. Hirsutane Sesquiterpenes from the Fungus Lentinus connatus BCC 8996. J. Nat. Prod. 2005, 68, 1674-1676. [CrossRef] [PubMed]

11. Swainsbury, D.J.K.; Zhou, L.; Oldroyd, G.E.D.; Bornemann, P. Calcium Ion Binding Properties of Medicago truncatula Calcium/Calmodulin-Dependent Protein Kinase. J. Biochem. 2012, 51, 6895-6907. [CrossRef] [PubMed] 
12. Radha Krishna, P.; Srivastava, A.K.; Ramaswamy, N.K.; Suprasanna, P.; D'Souza, S.F. Banana peel as substrate for $\alpha$-amylase production using Aspergillus niger. NCIM 616 and process optimization. Indian J. Biotechnol. 2012, 11, 314-319.

13. Andrews, J.M. BSAC standardized disc susceptibility testing method (version 8). J. Antimicrob. Chemother. 2009, 64, 454-489. [CrossRef] [PubMed]

14. Wotton, M. Methods for Antimicrobial Susceptibility Testing; British Society of Antimicrobial Chemotherapy (BSAC): Birmingham, UK, 2013.

Sample Availability: Samples of the compounds are not available from the authors.

(C) 2018 by the authors. Licensee MDPI, Basel, Switzerland. This article is an open access article distributed under the terms and conditions of the Creative Commons Attribution (CC BY) license (http:/ / creativecommons.org/licenses/by/4.0/). 